\title{
Konsep Cyber Notary Dalam Menjamin Keautentikan Terhadap Transaksi Elektronik
}

\author{
I Putu Suwantara ${ }^{1}$, Putu Angga Pratama Sukma ${ }^{2}$
}

${ }^{1}$ Fakultas Hukum Universitas Warmadewa, E-mail: bagustara108@gmail.com

2Fakultas Hukum Universitas Mahasaraswati Denpasar, E-mail: anggasukma@unmas.ac.id

\begin{tabular}{l}
\hline Info Artikel \\
\hline Masuk : 16 Januari 2021 \\
Diterima : 21 Januari 2021 \\
Terbit : 1 April 2021 \\
Keywords : \\
Cyber Notary; Authenticity; \\
Electronic Transactions \\
\\
\\
Kata kunci: \\
Cyber Notary; Keautentikan; \\
Transaksi Elektronik \\
Corresponding Author: \\
I Putu Suwantara \\
bagustara108@gmail.com
\end{tabular}

Info Artikel

Diterima : 21 Januari 2021

Keywords :

Cyber Notary; Authenticity

Electronic Transactions

Kata kunci:

Cyber Notary; Keautentikan

Corresponding Author:

I Putu Suwantara

10.24843/AC.2021.v06.i01.p15

\begin{abstract}
The purpose of this paper is to analyze the application form of the concept of cyber notary in guaranteeing the authenticity of electronic transactions and to examine notary arrangements in guaranteeing the authenticity of electronic transactions. This is a departure from the vagueness of norms in Article 15 paragraph (3) of the Law on Notary Position, regarding the need for legal norms on the function and role of notaries in electronic business transactions. This paper uses a normative legal research method because the focus of the study departs from the obscurity of norms. The form of application of the concept of cyber notary in guaranteeing the authenticity of electronic transactions is that the parties keep coming and dealing with the notaries. However, the parties immediately read the draft deed on their respective computers, after agreeing, the parties immediately signed the deed electronically at the notary's office. Notary arrangements in guaranteeing the authenticity of electronic transactions play a role in the issuance of electronic certificates through Electronic Certification Providers. The role of a notary for Certification Authority and in issuing Electronic Certificates through Electronic Certification Providers.
\end{abstract}

Abstrak

Tujuan penulisan ini adalah untuk menganalisa bentuk penerapan dari konsep cyber notary dalam menjamin keautentikan terhadap transaksi elektronik dan mengkaji pengaturan notaris dalam menjamin keautentikan terhadap transaksi elektronik. Hal tersebut beranjak dari adanya kekaburan norma dalam Pasal 15 ayat (3) Undang Undang Jabatan Notaris, akan kebutuhan norma hukum terhadap fungsi dan peran notaris dalam transaksi bisnis elektronik. Tulisan ini menggunakan metode penelitian hukum normatif karena fokus kajian beranjak dari kekaburan norma. Bentuk penerapan dari konsep cyber notary dalam menjamin keautentikan terhadap transaksi elektronik adalah para pihak tetap datang dan berhadapan dengan para notarisnya. Hanya saja, para pihak langsung membaca draft aktanya di masing-masing komputer, setelah sepakat, para pihak segera menandatangani akta tersebut secara elektronik di kantor Notaris. Pengaturan notaris dalam menjamin keautentikan terhadap transaksi elektronik berperan dalam penerbitan sertifikat elektronik melalui lembaga Penyelenggara Sertifikasi Elektronik. Peran notaris untuk Certification Authority maupun dalam penerbitan Sertifikat Elektronik melalui Penyelenggara Sertifikasi Elektronik. 


\section{Pendahuluan}

Kemajuan teknologi dan informasi merupakan sebuah kenyataan perkembangan peradaban dunia yang memberikan banyak akses bagi terjadinya perubahan pola kehidupan masyarakat dalam berbagai bidang. Teknologi komunikasi berkembang sangat pesat dan menggelobal di seluruh dunia termasuk di Indonesia. Dunia tanpa batas, "borderless world", begitu sering dikemukakan untuk menggambarkan betapa cepat dan pesatnya teknologi itu berkembang serta memainkan peranan yang sangat penting terutama dalam teknologi komunikasi seperti: menjadi penghubung antar individu, kelompok komunitas juga korporasi dalam waktu yang amat cepat dan spektakuler tanpa harus menghadirkan pihak-pihak yang berkomunikasi hadir berhadapan secara face to face. ${ }^{1}$ Notaris sebagai pihak ketiga terpercaya dalam era digital teknologi informasi bisa disebut sebagai cyber notary, yang dikemukakan dalam United Nation Commission on International Trade Law (UNCITRAL). Perkembangan notaris dalam UNCITRAL telah menggulirkan Model Law on E-Commerce pada tahun 1996, Model Law on E-Signatures pada tahun 2001, United Convention on the Use of Ecommunication in International Contracts pada tahun 2005, dan kajian tentang Promoting Confidence in E-Commerce: Legal Issues on International Use of Electronic Authentication and Signature Methods pada tahun 2009.2

Maka dari itu UNCITRAL dalam kajiannya berupa Promoting Confidence in ECommerce: Legal Issues on International Use of Electronic Authentication and Signature Methods sebagai langkah awal dalam menjamin transaksi elektronik. Dalam penjaminan transaksi elektronik notaris harus memiliki kredibilitas yang tinggi dan memiliki kebebasan tanpa terikat dalam pembuatan perjanjian atau akta yang dibuatnya memiliki legitimasi hukum. Pembuatan suatu akta dalam pendekatan secara histroris dimaknai dalam tiga hal sebagai pemaknaan filosofis, yakni:

1. Writing;

Writing dimaknai sebuah akta tersebut dapat ditulis dan dibaca mengenai unsur-unsur apa yang terkandung dalam suatu akta tersebut.

2. Sign;

Sign dimaknai sebuah akta adalah sebagai pemaknaan akan identitas dalam pembuatan akta dan sebagai simbol adanya persetujuan mengenai pembuatan akta tersebut.

3. Original;

Original dimaknai sebuah akta tersebut dapat dibawa dan dilihat kembali.

Original bisa dikategorikan akta sebagai adanya alat bukti yang menyatakan

bahwa para pihat adanya perikatan yang dimaknai dengan asas pacta sunt servanda.

\footnotetext{
${ }^{1}$ Dharmawan, N. K.,. (2015). Keberadaan Pemegang Saham Dalam Rups Dengan Sistem Teleconference Terkait Jaringan Bermasalah Dalam Perspektif Cyber Law. Udayana Master Law Jurnal. (4), 190-202. DOI: https://doi.org/10.24843/JMHU.2015.v04.i01.p15 .

2 Makarim, Edmon.,. (2011). Modernisasi Hukum Notaris Masa Depan: Kajian Hukum Terhadap Kemungkinan Cybernotary di Indonesia. Jurnal Hukum dan Pembangunan, (41)3, 287298. DOI: http://dx.doi.org/10.21143/jhp.vol41.no3.287.
} 
Dikatakan dengan adanya kajian UNCITRAL berupa Promoting Confidence in ECommerce: Legal Issues on International Use of Electronic Authentication and Signature Methods pada tahun 2009 terjadi perubahan dalam dunia Notaris mengenai peran dan fungsinya. Peran dan fungsi sebagai pihak ketiga terpercaya (trusted third parties) yang termuat dalam kongres The International Union of Notaries (UINL) pada tanggal 19-20 Oktober 2016 di Paris, Perancis dengan agenda yang dihasilkan adalah The Notary A Trusted Third Party. Tujuan dari UINL adalah:

"in a first section devoted to legal confidence, we will attempts to compile the needs which, according to the various stakeholders, justify recourse to a trusted third party. We will then be able to answers a first question: Why is the notary a trusted third party in legal matters."

"In a second section, we will examine the extent to which legal certainty strengthens and sustains economic security; this will allow us to re examine the aguments reasserting that the notary plays a pertinent role in today's economy".

Berdasarkan tujuan dari UINL tersebut diperlukannya pengembangan untuk menyatakan akan memperkuat peran dan fungsi Notaris dalam menjamin keberlanjutkan perekonomian yang tidak lepas dari fungsi notaris tersebut. Peran dan fungsi Notaris itu dalam UINL adalah sebagai berikut:

\section{Notary to Government}

Notary to Government dapat dimaknai Notaris sebagai pejabat umum dimana fungsinya memberikan pelayanan kepada masyarakat dalam membangun good governance menuju clean government dengan mengutamakan pelayanan yang profesional, cepat, tepat, efisien, murah dan bebas pungutan liar. Kemudian akan meningkatkan efektivitas dan efisiensi para Notaris dalam memberikan kepastian waktu penyelesaian pelayanan terhadap masyarakat, dengan demikian berdampak pada berkembangnya perdagangan dan perekonomian nasional dalam rangka meningkatkan kesejahteraan masyarakat. Misalkan seperti Notaris dalam pendaftaran fidusia online melalui Sistem Administrasi Badan Hukum (SABH).

2. Notary to Business

Notary to Busines dapat dimaknai Notaris sebagai pejabat yang berwenang untuk membuat suatu perjanjian ataupun akta dengan tujuan memberikan pelayanan kepada masyarakat untuk menjalankan bentuk suatu niaga dalam membuat perikatan antara para pihak dalam menjamin keamanan dalam berbisnis. Misalkan seperti Notaris membuat Kontrak Pengadaan Barang dan Jasa berbasis elektronik.

3. Notary to Society

Notary to Society dapat dimaknai Notaris sebagai pejabat yang terpercaya dimana fungsinya menjamin masyarakat dalam hal memberikan konsultasi atau penyuluhan hukum dan membuat wasiat dan perjanjian pra nikah secara elektronik. ${ }^{3}$

Mengenai melayani masyarakat di bidang bisnis secara elektronik Notaris berpegang teguh dengan hukum. Dasar pengaturan mengenai Notaris secara elektronik dapat dilihat dengan pemaknaan cyber notary, yang terdapat dalam Pasal 15 ayat (3) UndangUndang Republik Indonesia Nomor 2 Tahun 2014 Tentang Perubahan Atas Undang-

3 United Nation. Commision On International Trade Law. Available from https://uncitral.un.org/en/gateway. (Diakses 6 Januari 2020) 
Undang Nomor 30 Tahun 2004 Tentang Jabatan Notaris (Selanjutnya disebut UU PUUJN) yaitu "Selain kewenangan sebagaimana dimaksud pada ayat (1) dan ayat (2), Notaris mempunyai kewenangan lain yang diatur dalam peraturan perundangundangan". Pengertian Notaris mempunyai kewenangan lain yang diatur dalam peraturan perundang-undangan yang dimaksud dalam Undang Undang ini terdapat di Penjelasan yaitu "Yang dimaksud dengan "kewenangan lain yang diatur dalam peraturan perundang-undangan", antara lain, kewenangan mensertifikasi transaksi yang dilakukan secara elektronik (cyber notary), membuat Akta ikrar wakaf, dan hipotek pesawat terbang".

Secara sosiologis Notaris di Indonesia belum siap untuk mengemban posisi trusted third parties yang dikemukakan oleh UINL di Paris, Perancis. Hal tersebut masih terkendala dalam regulasi dan perangkat yang memadai. Padahal secara empiris transaksi elektronik banyak mengalami problematika dikarenakan tidak adanya suatu lembaga yang terpercaya dalam penyaksian yang berfungsi sebagai alat bukti adanya suatu perikatan. Salah satu problematika secara yuridis mengenai hambatan cyber notary adalah adanya Pasal 1 angka 2 Undang-Undang Republik Indonesia Nomor 11 Tahun 2008 Tentang Informasi dan Transaksi Elektronik (Selanjutnya disebut UU ITE) menyatakan "Transaksi Elektronik adalah perbuatan hukum yang dilakukan dengan menggunakan Komputer, jaringan Komputer, dan/atau media elektronik lainnya". Mengenai alat bukti tersirat dalam Pasal 5 ayat (4) yaitu "ketentuan mengenai informasi elektronik dan/atau dokumen elektronik sebagaimana dimaksud pada ayat (1) tidak berlaku untuk :

a. Surat yang menurut undang-undang harus dibuat dalam bentuk tertulis.

b. Surat berharga beserta dokumennya yang menurut Undang-undang harus dibuat dalam bentuk akta notaris atau akta yang dibuat oleh pejabat pembuat akta".

Berdasarkan hal tersebut maka dapat dirumuskan 2 (dua) permasalahan yakni bagaimanakah bentuk penerapan dari konsep cyber notary dalam menjamin keautentikan terhadap transaksi elektronik dan bagimanakah pengaturan notaris dalam menjamin keautentikan terhadap transaksi elektronik. Dari pemaparan diatas maka tujuan penulisan ini adalah untuk menganalisa bentuk penerapan dari konsep cyber notary dalam menjamin keautentikan terhadap transaksi elektronik dan mengkaji pengaturan notaris dalam menjamin keautentikan terhadap transaksi elektronik. Hal tersebut beranjak dari adanya kekaburan norma dalam Pasal 15 ayat (3) PUUJN, mengenai kewenangan mensertifikasi transaksi yang dilakukan secara elektronik. Pengertian mensertifikasi memiliki kekaburan makna apakah mensertifikasi tersebut memberikan sertifikat, melegalkan sertifikat atau notaris membuat sertifikat. Maka dari itu untuk menunjang peran Notaris dalam hal bisnis secara elektronik diperlukannya suatu kebutuhan norma hukum terhadap fungsi dan peran notaris dalam transaksi bisnis elektronik. Sehingga dibutuhkan suatu dekonstruksi norma dalam pengembangan dan pengamalan akan konsep trusted third parties dalam penyelenggaraan cyber notary.

State Of Art dalam penyusunan jurnal ini mengambil beberapa referensi penelitian sebelumnya termasuk jurnal-jurnal yang berhubungan dengan jurnal ini seperti yang tertera dalam Jurnal Hukum dan Pembangunan Volume 41, Nomor 3 atas nama Edmon Makarim tahun 2011 dengan judul Modernisasi Hukum Notaris Masa Depan: Kajian Hukum Terhadap Kemungkinan Cybernotary di Indonesia , yang kedua dalam 
Jurnal Acta Comitas Volume 2 atas nama Dewa Ayu Widyasari, R.A., Reno Murni dan I Made Udiana tahun 2017 dengan judul Kewenangan Notaris Dibidang Cyber Notary Berdasarkan Pasal 15 ayat (3) Undang Undang Nomor 2 Tahun 2014 Tentang Perubahan Atas Undang Undang Nomor 30 Tahun 2004 Tentang Jabatan Notaris, serta yang ketiga adalah dalam Jurnal Komunikasi Hukum (JKH) Volume 6, Nomor 1 atas nama Kadek Setiadewi dan I Made Hendra Wijaya tahun 2017 dengan judul Legalitas Akta Notaris Berbasis Cyber Notary Sebagai Akta Otentik.

\section{Metode Penelitian}

Tulisan ini menggunakan metode penelitian hukum normatif dengan fokus kajian dari adanya kekaburan norma, ${ }^{4}$ dalam pasal 15 ayat (3) UU PUUJN. Untuk menunjang penelitian tersebut, digunakan metode pendekatan: statute approach, conceptual approach, serta analytical approach. Sumber bahan hukum digunakan bahan hukum primer (primary sources) yang meliputi undang-undang dan bahan hukum skunder (secondary sources), seperti laporan hukum, catatan hukum, dan karya tulis hukum lainnya yang hanya memiliki kekuatan persuasif. Teknik penelusuran bahan hukum menggunakan tehnik studi dokumen, serta analisis kajian menggunakan analisis kualitatif. Penelitian ini juga menggunakan teknik penafsiran secara gramatikal dan penafsiran autentik (Teleologis). Penafsiran gramatikal dilakukan dalam rangka mencari arti atau makna isi aturan hukum.

\section{Hasil Dan Pembahasan}

\subsection{Bentuk Penerapan Dari Konsep Cyber Notary Dalam Menjamin Keautentikan Terhadap Transaksi Elektronik}

Sejarah notaris yang berakar dari "latijnse notariaat" romawi dalam perkembangannya mengalami resepsi yang berbeda di negara-negara yang menganut sistem hukum common law. Bilamana profesi notaris di negara-negara civil law pada umumya merupakan jabatan terhormat dan dihargai oleh masyarakat, di negara-negara common law para notaris yang dikenal dengan mana notary public sebaliknya tidak pernah menempati posisi yang terkemuka dalam praktek hukum. Hal ini antara lain menyebabkan studi tentang sejarah dan perkembangan notaris di negara-negara commom law sedikit diabaikan, terbukti dengan sedikitnya literatur yang membahas mengenai hal tertsebut, walaupun notary public sebagai profesi telah eksis dalam praktek selama berabad-abad. Sesungguhnya pemakaian istilah cyber notary di Indonesia sebagai Negara yang mewarisi tradisi Eropa Kontinental dirasakan kurang tepat. Berdasarkan literatur yang menerangkan sejarahnya, istilah cyber notary dan electronic notary seakan lahir dari dua konsep yang berbeda, yakni istilah e-notary yang

\footnotetext{
${ }^{4}$ Metode penelitian hukum normatif relevan diterapkan pada pengkajian hukum yang mengandung problematika norma kabur, norma kosong maupun norma konflik. Lihat Diantha, I. M. P. (2016). Metodologi Penelitian Hukum Normatif dalam Justifikasi Teori Hukum. Prenada Media. h. 12.
} 
dipopulerkan oleh ahli hukum dari Negara yang mewarisi tradisi civil law, sementara istilah cyber notary dipopulerkan oleh ahli hukum yang mewarisi tradisi common law. ${ }^{5}$

Dengan demikian pemakaian istilah e-notary di Indonesia sebagai Negara yang mewarisi tradisi civil law dirasakan lebih tepat. Hal tersebut dikemukakan dalam forum Trade Electronics Data Interchange System (TEDIS) legal workshop pada Konferensi TEDIS yang diselenggarakan oleh European Union tahun 1989 di Brussel. Esensinya adalah adanya suatu pihak yang menyajikan independen record terhadap suatu transaksi elektronik yang dilakukan para pihak. Sementara istilah cyber notary menurut Stephen Mason pada awalnya merupakan gagasan American Bar Association Information Security Committee tahun 1994. Berkenaan dengan pelaksanaan cyber notary tersebut, pada awalnya ketentuan mengenai pelayanan kenotariatan secara elektronik diharapkan dapat masuk ke dalam salah satu Pasal pada PUUJN. Namun hal tersebut tidak dapat dipenuhi. Meskipun begitu, Pasal 15 ayat (3) PUUJN mengatur bahwa notaris juga mempunyai kewenangan lain yang diatur dalam peraturan perundangundangan. Dalam penjelasan Pasal 15 ayat (3), kewenangan lain yang dimaksudkan tersebut adalah juga termasuk kewenangan mensertifikasi transaksi yang dilakukan secara elektronik atau cyber notary. Sesungguhnya kewenangan ini tidak terlalu tepat apabila dirujuk sebagai sertifikasi, karena makna yang dituju sebenarnya adalah penguatan atau menguatkan transaksi elektronik tersebut sehingga bisa dianggap sah secara hukum (legal). Salah satu bentuk penguatan atau legalisasi secara elektronik ini adalah dalam bentuk time stamp, atau mengesahkan terjadinya suatu transaksi pada waktu tertentu yang dilaksanakan antara para pihak. Bentuk legalisasi secara konvensional diantaranya adalah pengesahan tanda tangan dalam suatu dokumen, yang juga diatur sebagai salah satu kewenangan notaris berdasarkan UU PUUJN.

Beranjak dari nilai filosofis dalam Pasal 1 angka 1 UU PUUJN adalah "Pejabat umum yang berwenang untuk membuat akta autentik dan memiliki kewenangan lainnya sebagaimana dimaksud dalam undang-undang ini atau berdasarkan undang-undang lainnya". Secara filsafah mengenai kata keautentikan yaitu:

"To be authentic, one must truly be in harmony with his freedom. In existentialism, the notion of authenticity means really coming to terms with oneself, and then living accordingly. One must be able to come to terms with his identity while also not letting his background and history play a part in his decisión making process. Making choices should be done based on one's values, so that there is a responsibility that come with the decision making process. If one does not live within a balance of his freedom, he is inauthentic. It is in the inauthentic experience that people allow ideas like determinism, believing choices are meaningless, and acting as one should to persuade their choice making" . ${ }^{6}$ (Terjemahan sendiri: Untuk menjadi otentik, seseorang harus benarbenar selaras dengan kebebasannya. Dalam eksistensialisme, pengertian tentang keaslian berarti benar-benar berdamai dengan diri sendiri, dan kemudian hidup sesuai dengan itu. Seseorang harus dapat menerima identitasnya sementara juga tidak membiarkan latar belakang dan sejarahnya

\footnotetext{
${ }^{5}$ Makarim, Edmon.,. (2013). Notaris dan Transaksi Elektronik, Kajian Hukum tentang Cybernotary atau Electronic Notary. Rajawali Pers. h. 133.

6 Paul Klienman. (2013). Philosophy 101 "A Crash Course In The Principles Of Knowledge, Reality, And Values". F+W Media. Inc. h. 25.
} 
berperan dalam proses pengambilan keputusannya. Membuat pilihan harus dilakukan berdasarkan nilai-nilai seseorang, sehingga ada tanggung jawab yang menyertai proses pengambilan keputusan. Jika seseorang tidak hidup dalam keseimbangan kebebasannya, dia tidak autentik. Dalam pengalaman yang tidak autentik inilah orang membiarkan ide-ide seperti determinisme, percaya bahwa pilihan tidak ada artinya, dan bertindak sebagaimana mestinya untuk membujuk pengambilan pilihan mereka.)

Dekonstruksi dalam teori Derrida adalah sebuah strategi filsafat mengenai keauntentikan dan dalam Paul Klienman dapat didominasi dengan menginterpretasikan yang dihubungkan Pasal 1 angka 1 UU PUUJN sehingga penulis menafsirkan adalah:

1. One must be able to come to terms with his identity while also not letting his background and history yang di interpretasikan sebagai Notaris adalah pejabat umum;

2. To be authentic, one must truly be in harmony with his freedom. In existentialism, the notion of authenticity means really coming to terms with oneself, and then living accordingly yang di interpretasikan sebagai Notaris merupakan pejabat yang berwenang membuat akta autentik;

3. Making choices should be done based on one's values, so that there is a responsibility that come with the decision making process yang di interpretasikan sebagai terhadap pembuatan akta-akta itu tidak juga ditugaskan akta dikecualikan kepada pejabat lain atau orang lain yang ditetapkan oleh undang-undang.

Lebih lanjut dijelaskan, bahwasanya membuat pengalihan penyimpanan data secara elektronik hanya dapat berfungsi sebagai back up bukan sebagai salinan yang memiliki kekuatan hukum yang mengikat. Sebenarnya telah terbuka peluang terhadap kemungkinan untuk melakukan pembuatan akta dengan memanfaatkan perkembangan teknologi, namun problematika konsep cyber notary, terdapat dalam kewajiban Notaris dalam pembuatan akta, sebagaimana termaktub dalam pasal 16 ayat (1) huruf m yang menyebutkan bahwa Notaris berkewajban untuk "membacakan Akta di hadapan penghadap dengan dihadiri oleh paling sedikit 2 (dua) orang saksi, atau 4 (empat) orang saksi khusus untuk pembuatan Akta wasiat di bawah tangan, dan ditandatangani pada saat itujuga oleh penghadap, saksi dan Notaris.". Pasal tersebut lebih lanjut diterangkan dalam Penjelasan bahwa Notaris harus hadir secara fisik dan menandatangani Akta di hadapan penghadap dan saksi. Frasa "secara fisik" inilah yang menyebabkan konsep cyber notary atau pembuatan akta dengan memanfaatkan perkembangan teknologi tidak sesuai Dalam hal ini, menurut hemat Penulis antara kewajiban dan kewenangan Notaris mengalami benturan. Tidaklah memungkinkan untuk pelaksanaan pembuatan akta yang dalam konsepnya dilaksanakan secara remote dan praktis, untuk kemudian dibebankan kewajiban untuk menghadiri secara fisik. Kewajiban tersebut sejatinya menghilangkan unsur esensial dari konsep cyber notary.

Dalam hal konsep cyber notary yang oleh sebagian ahli hukum dikembangkan dengan pemanfaatan media elektronik secara telekonferensi, ternyata sebagaimana dikemukakan Edmon Makarim, selama ini ada sedikit kesalapahaman dalam menafsirkan frasa di hadapan sesuai Pasal 1868 KUH Perdata yang dikaitkan dengan 
cyber notary, ${ }^{7}$ hal ini mengidentikkan dengan pembuatan akta dilakukan secara telekonferensi, padahal tidak. Prinsip kerja cyber notary tidak jauh berbeda dengan notaris di dunia nyata. Para pihak tetap datang dan berhadapan dengan para notarisnya. Hanya saja, para pihak langsung membaca draft aktanya di masing-masing komputer, setelah sepakat, para pihak segera menandatangani akta tersebut secara elektronik di kantor Notaris.

\subsection{Pengaturan Notaris Dalam Menjamin Keautentikan Terhadap Transaksi Elektronik}

Ruang lingkup teknologi informasi, transaksi bisnis dipahami sebagai suatu perjanjian atau hubungan hukum antar pihak yang dilakukan dengan cara saling bertukar informasi untuk melakukan perdagangan. Dalam perkembangannya, kontrak yang dilakukan secara elektronik disebut dengan online contract atau electronic contract (econtract) yaitu perikatan atau hubungan hukum yang dilakukan secara elektronik dengan memadukan jaringan (networking) dari sistem informasi berbasis komputer (computer based information sistem) dengan sistem komunikasi yang berdasarkan atas jaringan dan jasa telekomunikasi (telecommunication based) yang selanjutnya difasilitasi oleh keberadaan jaringan komputer global internet (network of network).

Transaksi yang terjadi melalui e-commerce juga merupakan suatu perjanjian sama dengan perjanjian secara konvensional yang biasa dilakukan pada umumnya, hanya saja terdapat perbedaan pada media yang digunakan. Pada transaksi e-commerce yang digunakan adalah media elektronik yaitu internet, sehingga kesepakatan atau perjanjian yang terjadi akan melahirkan suatu kontrak elektronik (e-contraci). Kontrak Elektronik adalah kontrak baku yang dirancang, dibuat, ditetapkan, digandakan, disebarluaskan secara digital melalui situs internet (website) secara sepihak oleh pembuat kontrak (dalam hal ini pelaku usaha), untuk ditutup secara digital pula oleh penutup kontrak (dalam hal ini konsumen) ${ }^{8}$ dalam praktek dikenal beberapa jenis $e$ commerce, yaitu :

1. Business to Business ( $B$ to $B$ ), yaitu transaksi antar perusahaan (pembeli dan penjual adalah perusahaan). Biasanya diantara perusahaan tersebut telah saling mengenal satu sama lain dan sudah terjalin hubungan yang cukup lama. Pertukaran informasi hanya berlangsung diantara mereka dan didasarkan pada kebutuhan dan kepercayaan.

2. Business to Customer ( $B$ to $C$ ), yaitu transaksi antara perusahaan dengan konsumen/individu. Pada jenis e-commerce ini, transaksi disebarkan secara umum, dan konsumen berinisiatif untuk melakukan transaksi. Pelaku usaha harus siap menerima respon dari konsumen tersebut. Biasanya sistem yang digunakan adalah sistem Website karena sistem ini sudah umum digunakan di kalangan masyarakat.

\footnotetext{
7 Makarim, Edmon,. (2015). Interoperabilitas Identitas Digital Dalam Transaksi Elektronik Lintas Negara: Suatu Kajian Hukum Terhadap Sistem Identifikasi Dan Autentikasi Elektronik Menjelang Asean Community. Jurnal Hukum dan Pembangunan. (45)2, 229-240. DOI: 10.21143/jhp.vol45.no2.4

8 Gunawan, Johanes,. (2017). Reorientasi Hukum Kontrak di Indonesia, Jurnal Hukum Bisnis, (6)

1, 44-57. DOI: https://doi.org/10.24246/jrh.2020.v4.i2.p175-194 .
} 
3. Customer to Customer ( $C$ to $C$ ), yaitu transaksi perdagangan barang atau jasa antar konsumen atau antara individu.

4. Customer to Business ( $C$ to $B$ ), yaitu transaksi yang memungkinkan individu menjual barang atau jasa kepada perusahaan.

5. Customer to Government ( $C$ to $G$ ), yaitu sistem dimana individu dapat melakukan transaksi dengan pihak pemerintah, misalnya dalam hal membayar pajak. ${ }^{9}$

Jenis e-commerce yang sudah dikenal masyarakat umum dan paling banyak digunakan adalah jenis Business to Business dan Business to Customer. Transaksi melalui e-commerce ini memiliki beberapa ciri berikut:

1. Transaksi secara e-commerce memungkinkan para pihak memasuki pasar global secara cepat tanpa dirintangi oleh batas-batas negara

2. Transaksi secara e-commerce memungkinkan para pihak berhubungan tanpa mengenal satu sama lainnya

3. Transaksi melalui e-commerce sangat bergantung pada sarana (teknologi) yang kehandalannya kurang dijamin. Oleh karena itu, keamanan transaksi secara e-commerce ini belum atau tidak begitu dapat diandalkan.

Namun pada saat ini mengingat pengaturan global masih jauh dari kenyataan, maka yang perlu diusahakan adalah terciptanya harmonisasi maupun uniformitas seluas mungkin mengenai pengaturan yang dibutuhkan. Untuk mencapai harmonisasi dan uniformitas tersebut dibutuhkan studi perbandingan hukum yang luas, yang meliputi pembahasan aturan hukum dan praktek hukum negara asing, Model Laws yang tersedia di forum hukum asing, organisasi internasional serta analisis seberapa jauh hal-hal tersebut dapat diterima oleh hukum nasional. Upaya harmonisasi global yang menonjol adalah UNCITRAL Model Law on Electronic Commerce with Guide to Enactment (1996) ${ }^{10}$ yang ditambah dengan beberapa pasal pada tahun 1998 dan telah berpengaruh pada pembentukan peraturan e-commerce di beberapa negara.

Tujuan Model Law ini adalah untuk menganjurkan modernisasi peraturan hukum kontrak yang berlaku umum agar dapat mencakup kontrak elektronik. Pada intinya muatan UNCITRAL Model Law memuat ketentuan-ketentuan umum berikut:

1. Suatu data elektronik seperti halnya dokumen-dokumen hukum lainnya harus mengikat secara hukum

2. Suatu data elektronik dapat berisikan informasi yang dapat dipergunakan sebagai referensi

3. Suatu data elektronik adalah suatu tulisan untuk tujuan hukum, apabila dapat diakses sebagai referensi di kemudian hari

4. Suatu data elektronik mencakup suatu tanda tangan, apabila dapat diidentifikasi orang yang mengirim pesan tersebut dan indikasi bahwa orang tersebut telah menyetujui informasi dalam data tersebut

5. Suatu data elektronik merupakan suatu dokumen asli (original) apabila informasi yang dikandung dapat secara terpercaya dipertahankan dalam bentuk aslinya

9 United Nation. Commision On International Trade Law. Available from https://uncitral.un.org/en/gateway. (Diakses 6 Januari 2020). 10 Ibid. 
6. Suatu pertukaran data elektronik dapat menimbulkan suatu penawaran (offer) dan penerimaan (acceptance) dan karenanya membentuk suatu kontrak yang sah.

Hingga saat ini belum terdapat instrumen hukum yang mengatur mengenai legalisasi akta atau kontrak eletronik oleh notaris secara elektronik karena penandatanganan dan pengesahan tanda tangan elektronik memerlukan aturan khusus dan peran notaris dalam hal ini di Indonesia dilaksanakan oleh lembaga CA (Certification Authority) atau lembaga penyelenggara sertifikasi elektronik yaitu lembaga yang mengesahkan tanda tangan digital sebagai pihak ketiga independen yang memiliki wewenang untuk menerbitkan sertifikat digital yang berisi jati diri dari pengguna. Dengan keberadaan sertifikat digital ini maka pihak yang berhubungan dengan pemegang sertifikat digital dalam transaksi elektronik menjadi yakin bahwa otentisitas dari sertifikat itu terjamin.

Pelaku usaha dalam transaksi elektronik dapat disertifikasi oleh lembaga sertifikasi keandalan. Dalam Transakasi elektronik dikenal juga Sertifikasi Keandalan (SK) yang merupakan bukti bahwa pelaku usaha melakukan perdagangan secara layak dan merupakan logo sertifikasi (trust mark). Penyelenggara Sertifikasi Elektronik atau Lembaga CA ini sama dengan notaris di dunia nyata yang melakukan pengesahan terhadap tanda tangan elektronik sehingga memiliki kekuatan pembuktian yang sempurna. Di masa sekarang ini kemungkinan Notaris untuk diminta oleh klien nya untuk dilibatkan dalam suatu perjanjian yang merupakan produk dari suatu transaksi elektronik relatif besar, ini merupakan tantangan bagi profesi notaris dalam menanggapi globalisasi dalam dunia teknologi informasi, di sini artinya tugas Notaris sebagai pejabat publik berkembang seiring dengan perkembangan zaman. Dalam penelitian ini peneliti akan meneliti sejauh apa kemungkinan notaris untuk berperan dalam penerbitan sertifikat elektronik melalui lembaga Penyelenggara Sertifikasi Elektronik. Peluang yang akan diteliti meliputi peran notaris untuk melaksanakan keseluruhan wewenang Penyelenggara Sertifikasi Elektronik (Certification Authority) maupun peran notaris dalam penerbitan Sertifikat Elektronik melalui Penyelenggara Sertifikasi Elektronik.

Sertifikat Elektronik melalui Penyelenggara Sertifikasi Elektronik dalam dalam UU ITE sangat tidak relevan dikarenakan Pasal 5 ayat (4) huruf yaitu "ketentuan mengenai informasi elektronik dan/atau dokumen elektronik sebagaimana dimaksud pada ayat (1) menyatakan merupakan alat bukti hukum yang sah dan tidak berlaku untuk Surat berharga beserta dokumennya yang menurut Undang-undang harus dibuat dalam bentuk akta notaris atau akta yang dibuat oleh pejabat pembuat akta. Hal ini bertentangan dengan Pasal 1868 KUHPerdata menyebutkan "Suatu akta otentik ialah suatu akta yang dibuat dalam bentuk yang ditentukan undang-undang oleh atau dihadapan pegawai-pegawai umum yang berkuasa untuk itu, di tempat dimana akta itu dibuat", dan Pasal 1 angka (1) Undang- Undang Jabatan Notaris menyebutkan "Notaris adalah Pejabat Umum yang berwenang untuk membuat akta otentik dan kewenangan lainnya sebagaimana dimaksud dalam undang-undang ini". Pada dasarnya akta otentik mempunyai kekuatan pembuktian sempurna. 


\section{Kesimpulan}

Bentuk penerapan dari konsep cyber notary dalam menjamin keautentikan terhadap transaksi elektronik tidak jauh berbeda dengan notaris biasa. Para pihak tetap datang dan berhadapan dengan para notarisnya. Hanya saja, para pihak langsung membaca draft aktanya di masing-masing komputer, setelah sepakat, para pihak segera menandatangani akta tersebut secara elektronik di kantor Notaris.

Pengaturan notaris dalam menjamin keautentikan terhadap transaksi elektronik berperan dalam melegalisasi (sertifeing) dokumen elektronik dengan turut serta membubuhkan tanda tangan elektronik yang telah memiliki sertipikat digital diterbitkan oleh lembaga yang telah terafiliasi kepada lembaga CA (Certification Authority) yaitu kementerian Kominfo yang mana keseluruhan wewenang Penyelenggara Sertifikasi Elektronik (Certification Authority) maupun peran notaris dalam penerbitan Sertifikat Elektronik melalui Penyelenggara Sertifikasi Elektronik.

\section{Daftar Pustaka / Daftar Referensi}

\section{Buku}

Diantha, I. M. P. (2016). Metodologi Penelitian Hukum Normatif dalam Justifikasi Teori Hukum. Prenada Media.

Makarim, Edmon.,. (2013). Notaris dan Transaksi Elektronik, Kajian Hukum tentang Cybernotary atau Electronic Notary. Rajawali Pers.

Paul Klienman. (2013). Philosophy 101 "A Crash Course In The Principles Of Knowledge, Reality, And Values". F+W Media. Inc.

\section{Jurnal}

Dharmawan, N. K.,. (2015). Keberadaan Pemegang Saham Dalam Rups Dengan Sistem Teleconference Terkait Jaringan Bermasalah Dalam Perspektif Cyber Law. Udayana Master Law Jurnal. (4), 190-202. https://doi.org/10.24843/JMHU.2015.v04.i01.p15 .

Gunawan, Johanes,. (2017). Reorientasi Hukum Kontrak di Indonesia, Jurnal Hukum Bisnis, (6) 1, 44-57. DOI: https://doi.org/10.24246/jrh.2020.v4.i2.p175-194 .

Makarim, Edmon,. (2011). Modernisasi Hukum Notaris Masa Depan: Kajian Hukum Terhadap Kemungkinan Cybernotary di Indonesia. Jurnal Hukum dan Pembangunan, (41)3, 287-298. DOI: http://dx.doi.org/10.21143/jhp.vol41.no3.287.

Makarim, Edmon,. (2015). Interoperabilitas Identitas Digital Dalam Transaksi Elektronik Lintas Negara: Suatu Kajian Hukum Terhadap Sistem Identifikasi Dan Autentikasi Elektronik Menjelang Asean Community. Jurnal Hukum dan Pembangunan. (45)2, 229-240. DOI: 10.21143/jhp.vol45.no2.4 
Widyasari, Dewa Ayu., Murni, R.A., Reno., Udiana, I Made., (2017). Kewenangan Notaris Dibidang Cyber Notary Berdasarkan Pasal 15 ayat (3) Undang Undang Nomor 2 Tahun 2014 Tentang Perubahan Atas Undang Undang Nomor 30 Tahun 2004 Tentang Jabatan Notaris. Jurnal Acta Comitas. (2) 2, 219-227.

\section{Internet}

United Nation. Commision On International Trade Law. Available from https://uncitral.un.org/en/gateway. (Diakses 6 Januari 2020).

\section{Undang-Undang}

Kitab Undang- Undang Hukum Perdata (Staatsblaad Nomor 23 Tahun 1847 Tentang Burgerlijk Wetboek) (Staatsblad No. 23 Tahun 1847);

Undang-Undang Republik Indonesia Nomor 11 Tahun 2008 Tentang Informasi Dan Transaksi Elektronik (LN No. 58-TLN No. 4843);

Undang-Undang Republik Indonesia Nomor 2 Tahun 2014 tentang Perubahan atas Undang-Undang Nomor 30 Tahun 2004 tentang Jabatan Notaris (LN No. 3-TLN No. 5491). 